\title{
The management of risk and investment in cell therapy process development: a case study for neurodegenerative disease
}

\author{
Sujith Sebastian', Paul Hourd ${ }^{1}$, Amit Chandra1, David J Williams ${ }^{1}$ \& Nicholas Medcalf*,1 \\ ${ }^{1}$ Centre for Biological Engineering, Wolfson School of Mechanical, Electrical \& Manufacturing Engineering, Loughborough \\ University, Loughborough, Leicestershire, LE11 3TU, UK \\ *Author for correspondence: n.medcalf@lboro.ac.uk
}

\begin{abstract}
Cell-based therapies must achieve clinical efficacy and safety with reproducible and cost-effective manufacturing. This study addresses process development issues using the exemplar of a human pluripotent stem cell-based dopaminergic neuron cell therapy product. Early identification and correction of risks to product safety and the manufacturing process reduces the expensive and time-consuming bridging studies later in development. A New Product Introduction map was used to determine the developmental requirements specific to the product. Systematic Risk Analysis is exemplified here. Expected current valuebased prioritization guides decisions about the sequence of process studies and whether and if an early abandonment of further research is appropriate. The application of the three tools enabled prioritization of the development studies.
\end{abstract}

First draft submitted: 29 June 2018; Accepted for publication: 8 April 2019; Published online: 18 June 2019

Keywords: cell differentiation $\bullet$ decision trees $\bullet$ dopaminergic neurons $\bullet$ induced pluripotent stem cells $\bullet$ investment - Parkinsonian disorders $\bullet$ Parkinson's disease $\bullet$ phenotype $\bullet$ pluripotent stem cells

\section{Introduction: a developmental dilemma}

Regenerative medicine offers hope for many diseases [1]. Such complex products present significant translational challenges. The development of advanced therapy medicinal products (ATMPs), specifically cell-based medicinal products (CBMPs), has several features that are largely absent from processes for noncellular medicines:

- The sector contains many young companies who need revenue early. They must avoid long development timelines and placing large volumes of capital at risk

- The starting and raw materials can be highly variable

- The processes may need 'hold steps' in order to be manageable

- The process is often based upon largely manual operations derived from research activity

Many products are being developed in academia and the pressure to obtain clinical results can result in a gap in process and product understanding [2]. A process change late in development may result in expensive bridging studies, delaying launch and introducing the risk that the product from the revised process may not perform adequately. Successful decisions in CBMP development are therefore early decisions [3]. However, until the efficacy of the product is known from clinical trials the developers cannot know whether such early investment will pay off. Effective, quantitative decision-making tools are needed. In this paper we consider three tools that we have applied. We demonstrate the techniques using the manufacture of neural progenitor cells from pluripotent stem cells (PSCs). The study arises from the UK Regenerative Medicine Platform program (see acknowledgments).

For clarity we have ignored many small decisions, concentrating instead on two big decisions that must be addressed in process development. Firstly, this process needed at least one 'hold step,' in other words, a pause from which multiple manufacturing campaigns can be managed. We refer to this as the 'hold step question.' Secondly, we prioritized the garnering of efficacy data versus fixing process design for full-scale. We refer to this as the 'development dilemma'. The two choices are illustrated in Figures $1 \& 2$. 


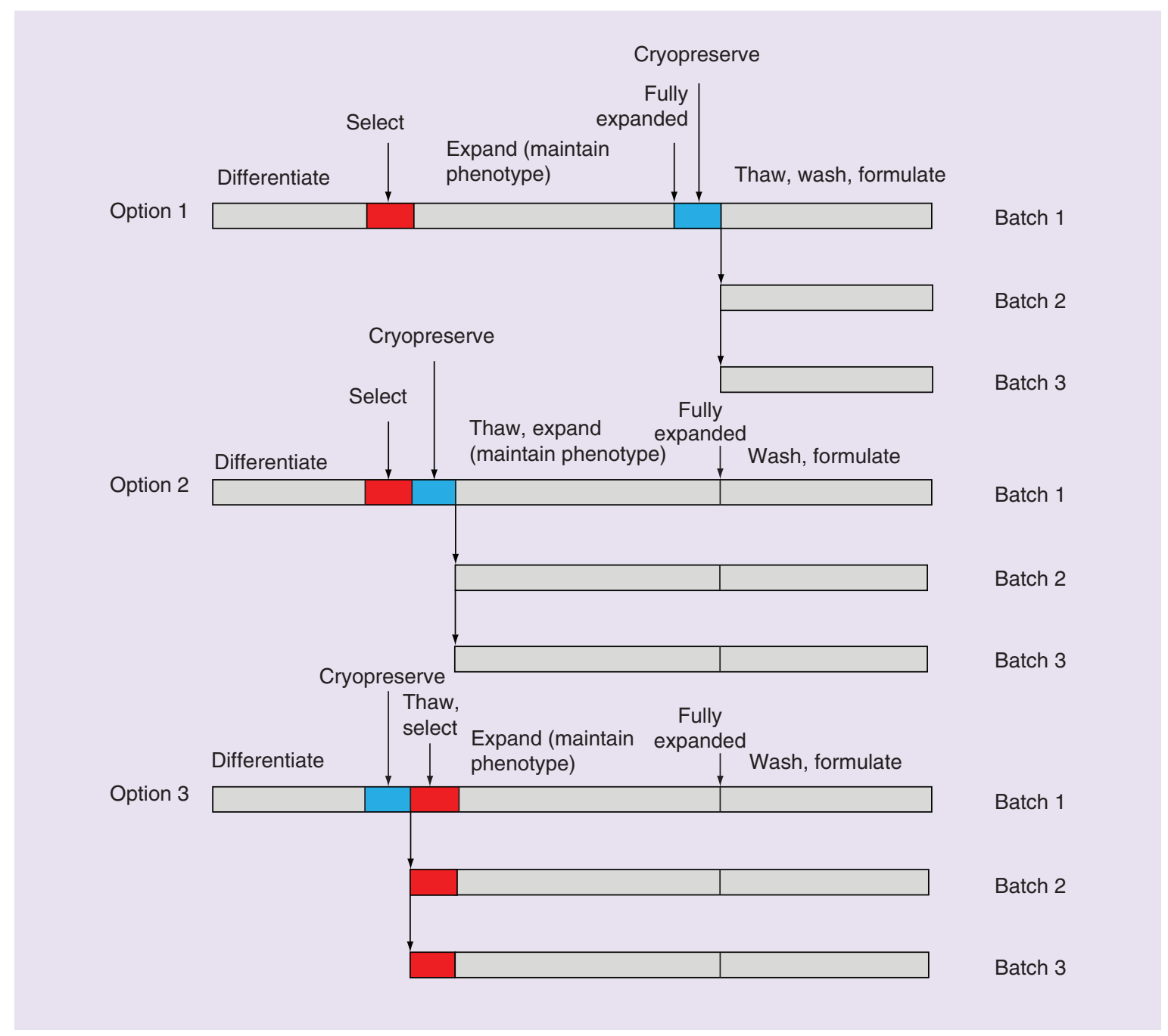

Figure 1. The 'hold step' question. This figure describes a hypothetical product development scenario with representative potential options that can be applied to the end-to-end product manufacturing process for multiple batches. Introduction of a hold step, referred to as 'cryopreserve,' and a 'select' step for desired cell types that maintain phenotype at different stages of the differentiation process alters the key process steps involved in the development.

There are three main stages in the process. The Master Cell Bank is established at the stage before lineage commitment. The Master Working Cell Bank is then established from the Master Cell Bank. These two steps are not the subject of this analysis. Campaigns of cell differentiation to the neural progenitor phenotype are followed by selection of the preferred cell clones and expansion. This provides cells from which the final product may be formulated. The question is therefore whether it is better to establish a hold step (marked 'cryopreserve' in the figure) following expansion, or following selection or following differentiation.

As the organization gains knowledge, it can rely more heavily on know-how from this early manufacturing research but in the early days this will not be possible. The alternative is to proceed to trials with relatively little process knowledge and to impose a narrow manufacturing protocol. If development is later abandoned due to lack of efficacy then the financial loss has been minimized.

\section{The tools that were applied}

- A New Product Introduction map (NPI map) to provide high-level guidance about characterization and manufacturability;

- A Risk Based Approach to identifying the major gaps in process and product quality; 


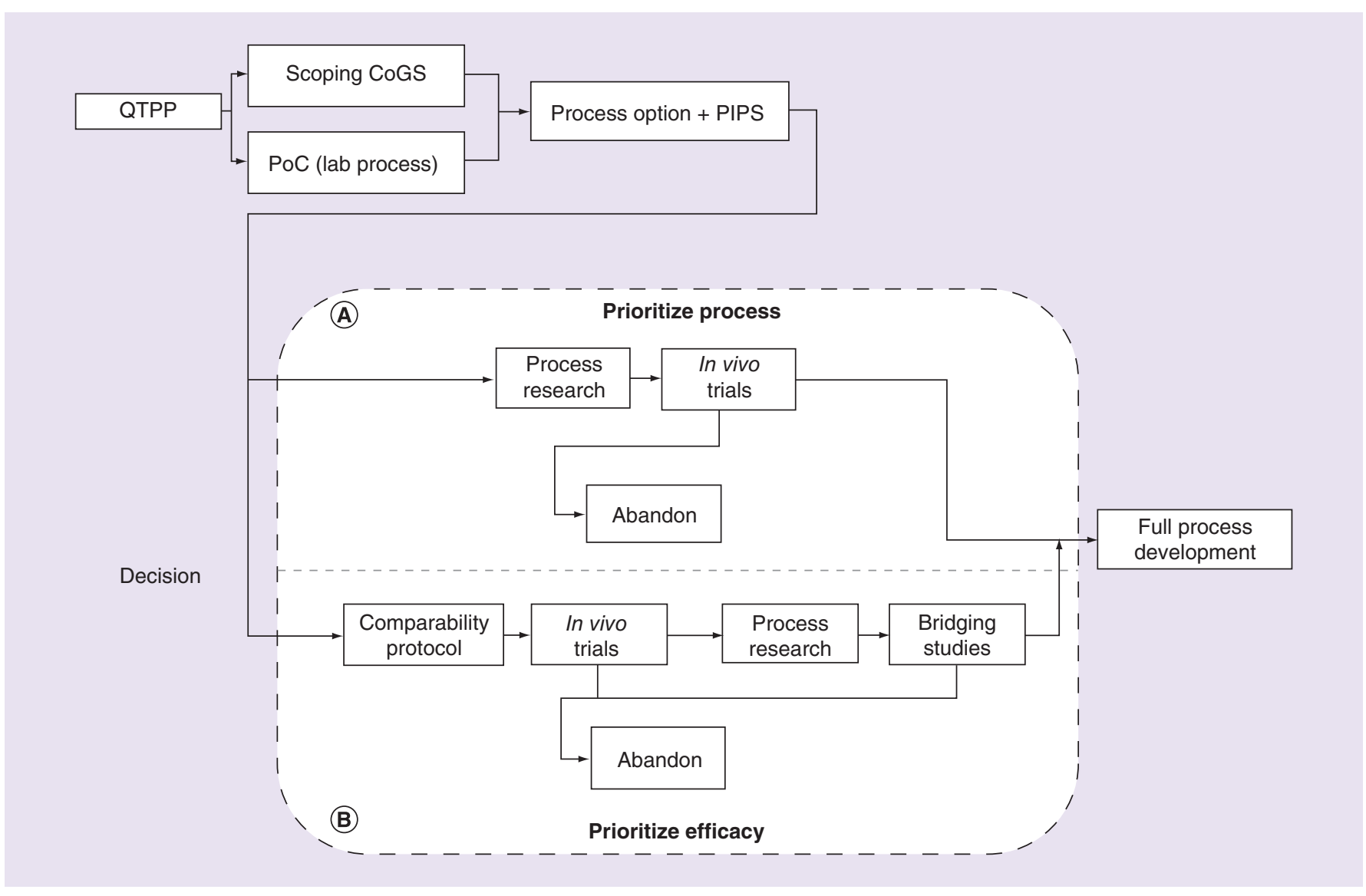

Figure 2. The 'development dilemma' in cell therapy product development. This figure represents two alternative routes of investment decision in the product development programme. In the process research prioritized route, early investment in process research supports progression into full process development after clinical trials are proven to be efficacious (A). In the alternative route to prioritize efficacy, with the provision of a predesigned comparability protocol, further process research has to be conducted after clinical trials are proven to be efficacious with the potential risk of bridging studies and time delay before full process development for commercial release (B). CoGS: Cost of goods supplied; PIPS: Provisional in-process specification; PoC: Proof of concept; QTPP: Quality Target Product Profile.

- An Expected Current Value (ECV) method designed to identify the preferred sequence of research investments that will be needed.

Their interrelationship is shown in Figure 3.

\section{Case study}

The process was to manufacture dopaminergic (DA) neurons for clinical use in patients with Parkinson's disease (PD). Our study examined three protocols at a stage where they were ready for clinical translation. The methods were compared in terms of their readiness for manufacture. The NPI map was used to guide the timing of development activity, especially the timing of the means of characterization. A risk-based approach prioritized studies that close gaps in process understanding. At this point ECV calculations were used to manage the 'development dilemma'.

\section{Parkinson's disease}

$\mathrm{PD}$ is a progressive neurodegenerative disease that affects around one percent of the global population by age 65 years. It is currently incurable. The pharmacologic interventions, including L-Dopa, or dopamine agonists help to manage the disease only in the early stages [4]. More invasive methods, such as deep brain stimulation [5] and lesioning have been investigated as well. Cell replacement, such as implantation of neural progenitors, is now practical [6]. Transplantation of fetal neuron cells [7] was a revolutionary step and achieved long-lasting improvement in the condition of some patients [8]. Although the method proved that fetal ventral mesencephalic neurons can survive 


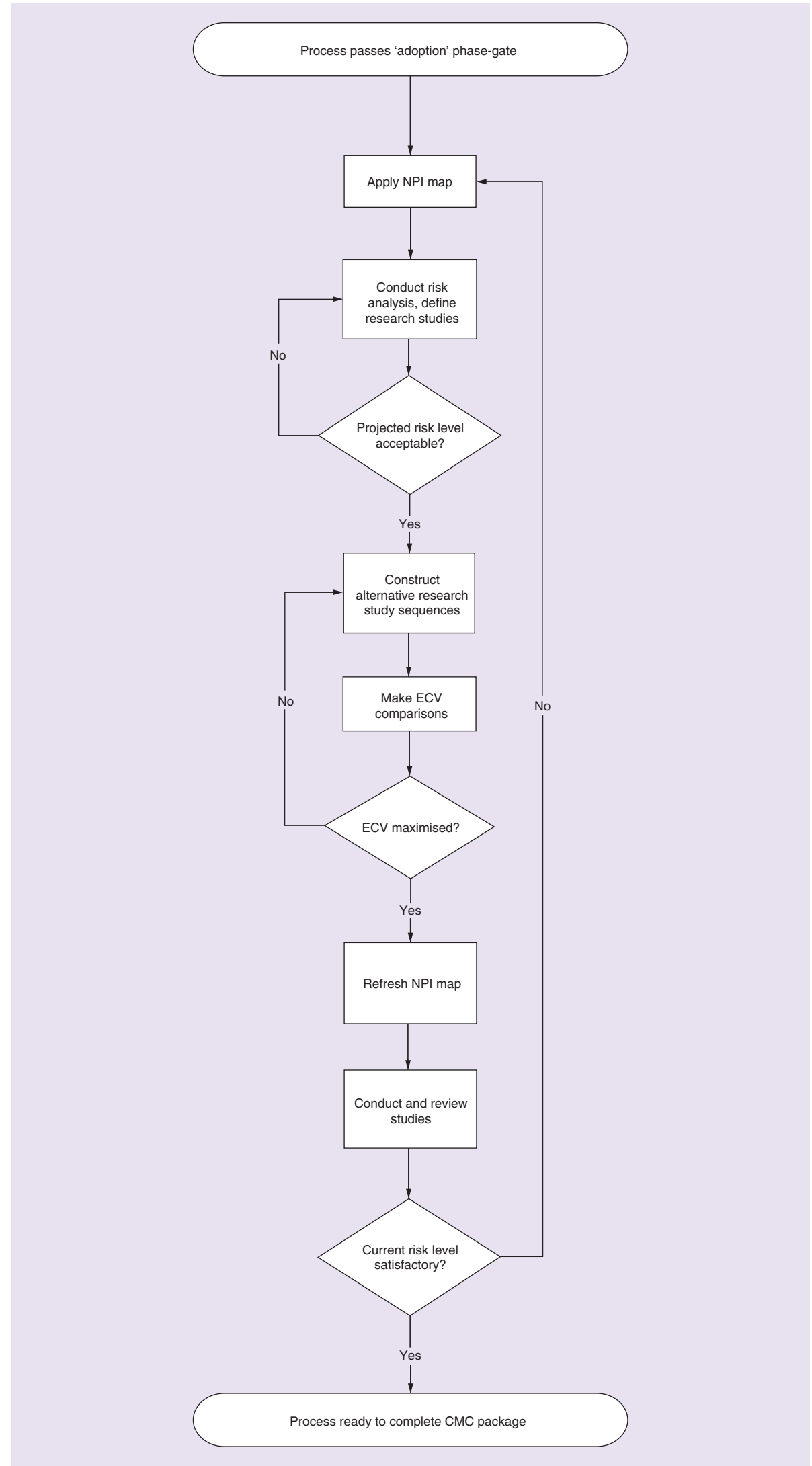

Figure 3. Methodology: inter-relationship of the tools. The decision tool flow chart presented here acts as a high level decision choice for the implementation of New Product Introduction tool. As detailed in the flow chart, a risk analysis and resultant acceptable level of risks leads to an expected current value comparison to maximize value and an improved New Product Introduction map step which leads to product commercialization.

CMC: Chemistry, manufacturing, and control; ECV: Expected current value; NPI: New Product Introduction map. 


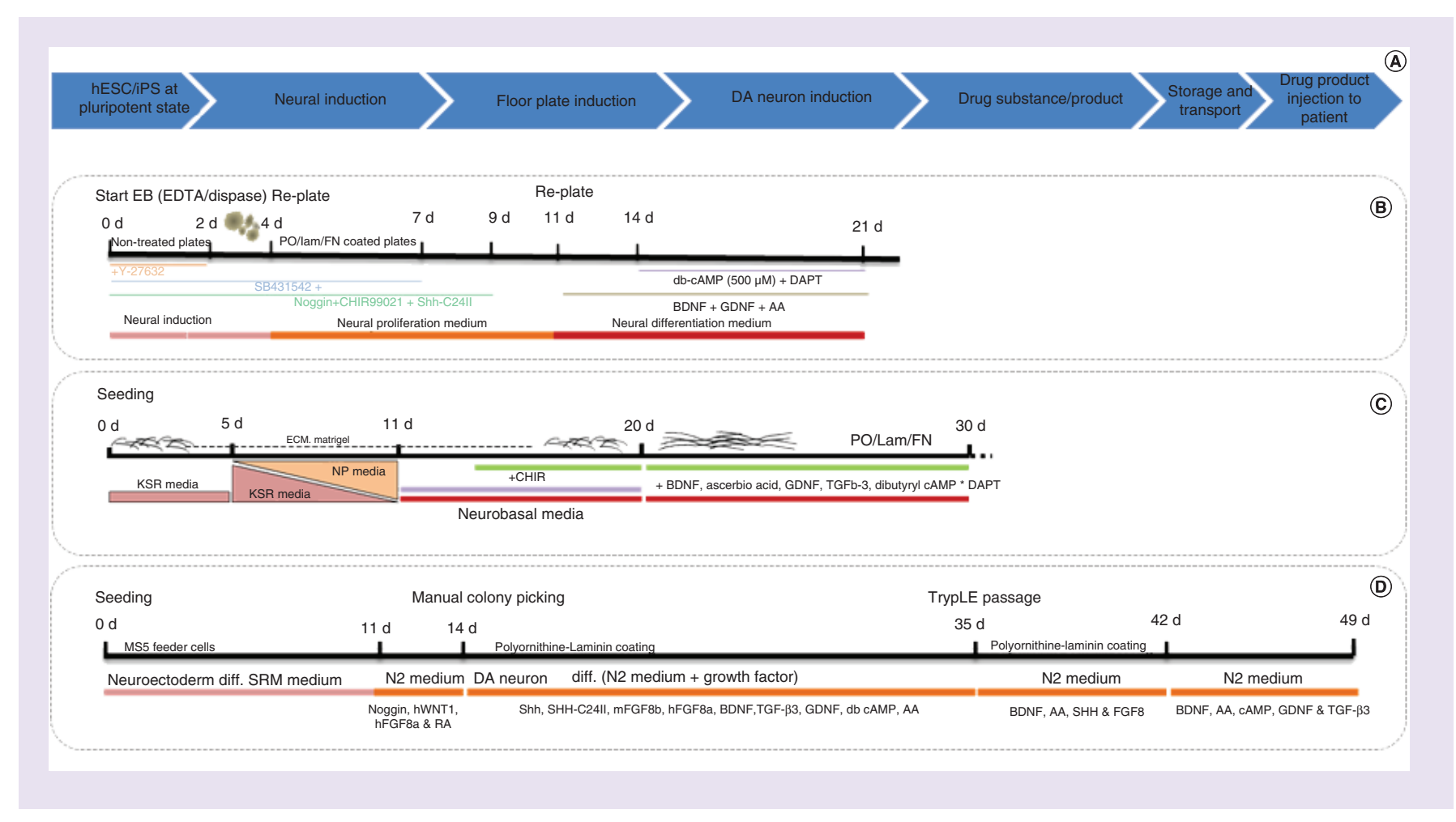

Figure 4. Dopaminergic neuron differentiation processes. Major process steps involved in the dopaminergic neuron product manufacture (A). DA neuron differentiation process diagrams show the three processes described in this article. Process length is represented by the black line with days of differentiation noted on top of the line (e.g., $21 \mathrm{~d}=$ day 21 of differentiation). The type of culture medium and the major differentiation reagents and patterning factors required during the specific stages of differentiation is shown below the line that indicates process length. Representative DA neuron differentiation developed by Kirkeby et al. (2012) (B), process developed by Kriks et al. (2011) (C), process developed by Hallett et al. (2015) (D). DA: Dopaminergic; hESC: Human embryonic stem cell; iPS: Induced pluripotent stem cell.

and integrate, ethical issues and the limited availability of the fetal tissue have driven the search for alternatives. PSCs from human blastocysts ('human embryonic stem cells' or hESCs) provide a potentially unlimited source of cells with the ability to differentiate into any human cell type [9]. Ethical issues are avoided by using induced PSCs (iPSCs) [10]. hESCs, when differentiated into neural progenitors, express different neural markers and have potential neurological function [11]. Recent advances with hESCs and iPSCs under directed differentiation give DA neuron precursors with the appropriate profile for treatment of $\mathrm{PD}$ patients.

\section{Developing CBMPs for PD}

In Australia, clinical trials have been conducted using stem cells of parthenogenetic origin [12]. Another clinical trial is planned by Chinese surgeons using hESCs [13]. Promising claims are being made by researchers in the UK, Sweden, the USA and Japan using hESC or iPSC cell therapy approaches [14-16].

Malin Parmar and colleagues at Lund University, Sweden, have developed a protocol [17] to generate DA neurons from hESCs. The resultant cells integrate into the striatum of murine models of PD. The level of differentiation, integration and disease reversal was comparable to the results from human fetal ventral mesencephalic neurons [18], the current 'gold standard' in cell therapy for PD.

Lorenz Studer's group at Memorial Sloan-Kettering Cancer Center, USA, has made substantial progress unravelling the molecular mechanisms of PSC differentiation into DA neurons. The Group's Good Manufacturing Practice (GMP)-compliant protocol is ready for clinical trials starting either from hESCs or iPSCs [19]. Preclinical in vivo results in mouse and monkey PD models starting from hESCs or iPSCs show integration and reversal of disease symptoms $[19,20]$.

Ole Isacson's group at Harvard University showed that DA neurons from non-human, primate-derived iPSCs, transplanted into the brain of histocompatible primate PD models integrated and reversed disease conditions [20]. 
These three methods were compared to analyse the risks associated with any commercial manufacturing process based upon them and any consequent product risk to patients.

\section{DA neuron process description}

Some key process issues were addressed during early research. These included the replacement of serum with 'Knockout Serum' (a chemically-defined, serum-free formulation) and replacement of feeder cell layer with a coating of extracellular matrix. The planned development was to substitute xeno-free medium components for animal-derived raw materials. At the time of writing these protocols were not fully compatible with GMP because the cell lines were maintained on a mouse embryonic fibroblast layer and serum had been used at early stages of cell line development. A recent report of an hESC line derived under GMP conditions [21] may be the first of its kind. When the product is to be autologous it is important to apply quantitative methods to qualify the starting material. Examples are the determination of the level of genetic stability, reliable and repeatable cell counting methods, determination of viability and quantitative morphological analysis. The following process steps were common to all three processes:

- A qualitative method of selection of PSCs for differentiation

- Induction of cell starting material into neural progenitors that acquired neural fate

- Directed differentiation into the DA neuroprogenitor stage that can differentiate into DA neuron under terminal differentiation

- Formulation and, potentially, cryopreservation

- Transportation to the clinic

- Transplantation

Neural progenitor cells or the neuroprogenitor cells are the resultant intermediate stage cell in a directed differentiation process which acquired neural fate. These cells can be differentiated into multiple types of cells with positional identity under the presence of different patterning factors and their concentrations [17]. DA neuron progenitors are used for the transplantation.

The overall process length varied significantly between the three processes (Figure 4).

\section{'Freezing' the process design}

Before process engineers can begin work it is necessary to 'freeze' the process. From this point on adjustments must take place in a controlled manner and records must be subject to version control. A 'Quality Target Product Profile' (QTPP) of the product will guide the decision about when the process is ready to be frozen. The correlation between this and potential efficacy is defined as development proceeds. The pathways for collecting data for the submission package are less well developed for ATMPs than for pharmaceuticals [22]. Nevertheless, there is a close relationship between potency assays and overall batch quality and the assays must be identified early in development. Changes to the impurity profile of a batch may invalidate the method of analysis. Best practice is to develop and validate an assay in relation to the formulation excipients.

\section{Tool 1: new product introduction map}

The NPI process (Figures $5 \& 6$ ) is based upon input from various stakeholders. It identifies the prerequisites of facilities and of product assays. There are critical phase-gates for 'Stop/Go' decisions. For robust process design, the choice of characterization methods should consider more than simply the idea of testing to specification. The insight so gained will enable identification and control of critical process parameters that affect the Critical Quality Attributes. During this process the NPI map acts as a framework to acquire, prioritize and organize the growing body of information. It comprises a logic map (Figure 5) and an approximate sequence of events (Figure 6). It sets out the interrelationship between the decisions, each of which is then addressed in detail in the Risk-Based Approach (Tool 2).

\section{Tool 2: risk-based approach}

Specific risks must be identified and managed before any clinical use may take place. Nonclinical and clinical data will be needed to justify any action that is taken to mitigate the risks. The timing and scope of the risk assessments in Figures $5 \& 6$ and will vary according to the maturity of the process. 


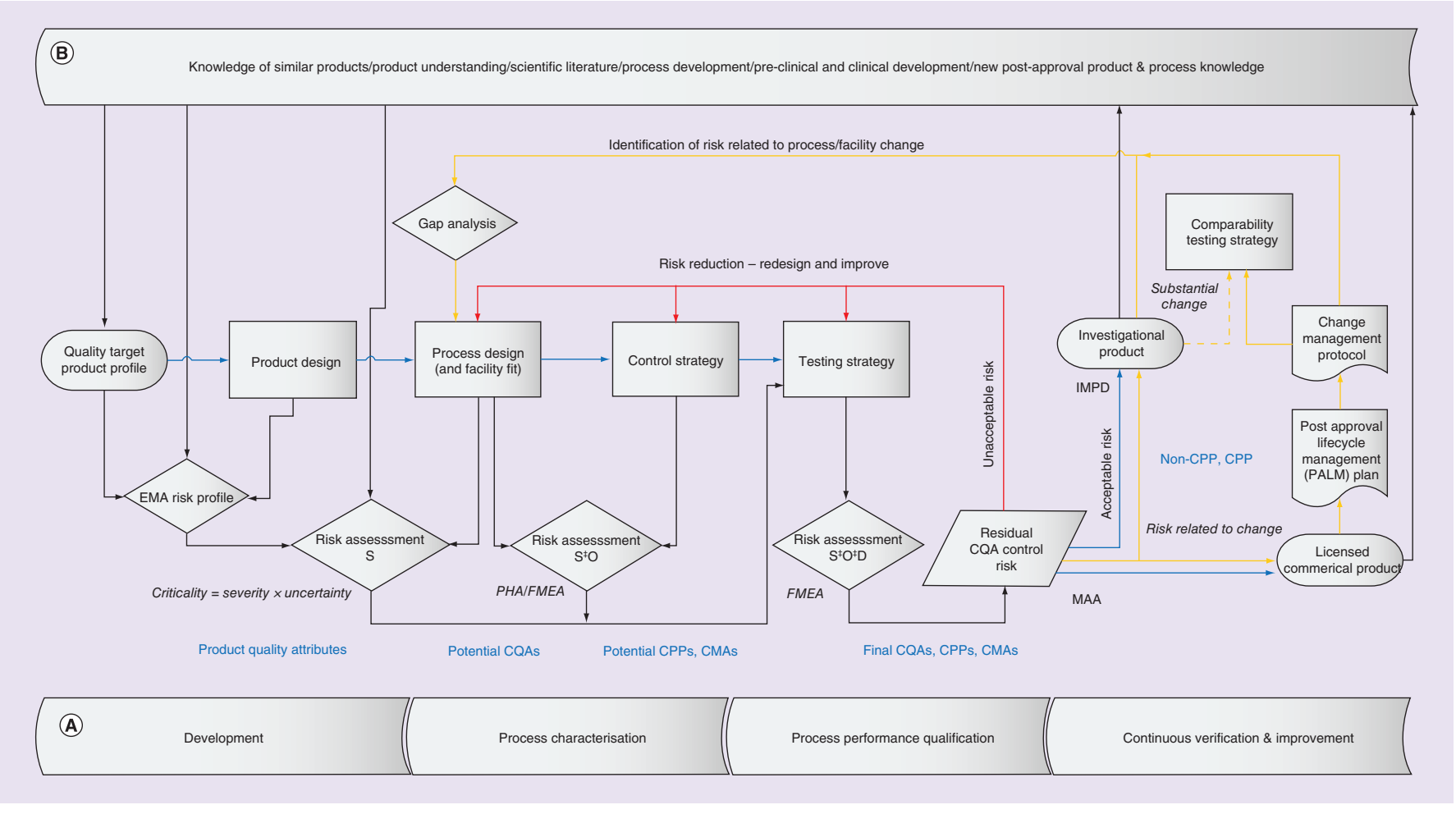

Figure 5. High level risk assessment framework to assess process risk. The risk assessment framework illustrated here provides a high level decision tool to determine the risks associated with the product development at different stages. General product development stages are shown in the bottom pane (A). Existing/potential product knowledge categories contributing to the generation of Quality Target Product Profile (QTPP) are shown in the top pane (B). The development process starts with the generation of a QTPP based on the existing knowledge mentioned in the top pane and the product design is dependent on this knowledge. The risk analysis of the QTPP and product design recommended by the European Medicines Agency leads to the determination of criticality of the risks. Criticality of risks is a culmination of severity, chances of occurrence and detectability of the risk (shown in red). Sequential risk assessment of process design, control strategy and testing strategy with its risk criticality score enables calculation of the residual CQA control risk. An unacceptable risk level endorses process improvement, redesign and risk reduction actions (indicated with red arrow). The risk assessment is to be conducted as an iterative process to further assess the risk criticality, when the risk level reaches to an acceptable level development proceeds to Investigative Medicinal Product Development (indicated with blue arrow). The knowledge gained from preclinical/clinical studies (B) further assists the process improvement by reduction of risks (black arrows from top pane). This reiterative risk analysis and risk reduction programme allows progression to Marketing Authorization Application and commercial licensing. Inevitable changes to the product or process during the product lifecycle have to be further addressed with a comparability testing strategy (indicated with yellow arrow). The risk analysis and process improvement is a reiterative process to apply at every stage of the product development.

CMA: Critical Material Attribute; CPP: Critical Process Parameter; CQA: Critical Quality Attribute; D: Detectability; FMEA: Failure Mode and Effects Analysis; IMPD: Investigational Medicinal Product Dossier; O: Occurance; MAA: Marketing Authorization Application; QTPP: Quality Target Product Profile; S: Severity.

We conducted the risk assessment by tabulating the risks by category in relation to the stages of the process (see Tables 1-3).

To be useful the risks must be amenable to classification and decision making. We applied an open source risk analysis matrix. The classification of risks is made by combining the likelihood of occurrence with the consequence for the product or process. Likelihood of the risks was categorized as follows:

Risk probability of occurrence: 1 in 10 = 'almost certain'; 1 in $100=$ 'likely'; 1 in 1000 = 'possible' and so on, in logarithmic steps to 'unlikely' and 'rare'.

Risk consequences were categorized based on the estimated percentage loss of the total value of the product. Potential losses were calculated based on the process- and product-dependent risks. 'Insignificant' or 'minor' risk categories are 0.001 to $0.01 \%$ respectively of total product value and may include very limited reputational damage. 'Moderate' risk, e.g. a risk that product may fail to meet internal standards only, does not have long-term consequences and involves limited damage to reputation with potential financial loss of about $1 \%$ of product value. 'Major' risk involves fatality, permanent disability or emotional injury to limited numbers of patients, lack 


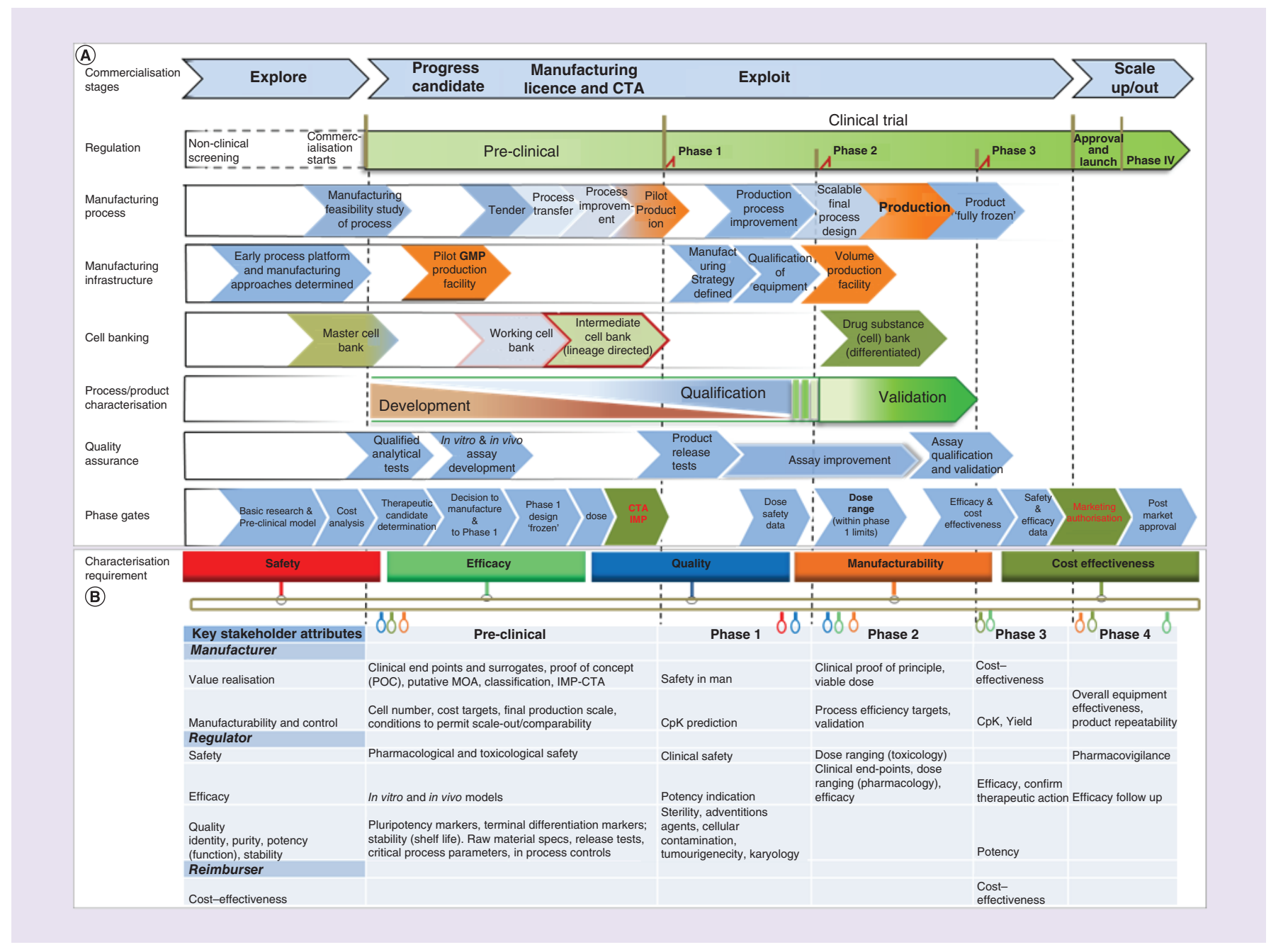

Figure 6. Cell-based medicinal product-specific New Product Introduction map. The New Product Introduction map represents high level product-dependent stages and requirements relevant to specific stages of the product development. The map contains two sections. (A) shows the steps in development as lists of chevrons. Colors used in this section are for illustrative purpose only. (B) uses color-coded rectangular boxes (safety, efficacy, quality, manufacturability and cost-effectiveness) to link to the table beneath with hook-shaped tabs in same color. The dotted vertical line at the boundary of every stage of the preclinical or clinical phases represents a preferred stage gate at which the necessary product development related to that stage gate need (arranged in the parallel strands) must be complete e.g. a working cell bank and intermediate product cell bank to be made ready before entering into clinical Phase I. The table shown at the bottom of the figure in (B) represents the characterization requirements relevant at specific stages of the product development during preclinical and clinical trial phases.

CTA: Clinical Trial Authorization; GMP: Good Manufacturing Practice; IMP: Investigational medicinal product.

of product efficacy, failure to meet claimed standards, long-term consequences, loss of credibility and reputation, national press interest and financial loss of $10 \%$ of product value. 'Catastrophic' risk involves fatalities, disabilities or emotional injury to many patients, lack of efficacy, major long term consequences, major public or political concern and financial losses exceeding $25 \%$ of total product value.

\section{Risk rating}

Based on the likelihood and the consequences, risks were classified into 'high', 'medium' and 'low' categories overall. The strategy is shown in Table 4. Risk of the product to patients is shown in Table 5. Process-specific risks are indicated in Table 6. Since the risks in CBMPs for PD mostly fall into 'high' or 'moderate' assessment categories, great care must be taken over prevention. 


\begin{tabular}{|c|c|c|}
\hline Risk factor & Major risks & Evidence and mitigation \\
\hline \multirow{6}{*}{$\begin{array}{l}\text { Starting material } \\
\text { hESCs and iPSCs. } \\
\text { hESC line H9 used commonly in } \\
\text { studies, others including H1, iPSC } \\
\text { lines } 2 \text { C6 and SeV6 }\end{array}$} & Tumor formation & $\begin{array}{l}\text { hESCs/iPSCs acquired inherent capacity to form teratoma [23] but fully differentiated cells which lack } \\
\text { the expression of proliferation marker did not result in tumor upon transplantation in mouse } \\
\text { brain [24] }\end{array}$ \\
\hline & $\begin{array}{l}\text { Unwanted } \\
\text { immunogenicity }\end{array}$ & $\begin{array}{l}\text { hESC-derived DA neurons transplanted in rhesus monkey resulted in immunogenicity [25]. } \\
\text { Primate-derived iPSC differentiated DA neurons survived in primate brain without any } \\
\text { immunosuppression [26]. Similarly autologous transplantation of primate iPSC-derived DA neurons } \\
\text { survived in primate brain after } 2 \text { years without immunosuppression }[21,27]\end{array}$ \\
\hline & Treatment failure & $\begin{array}{l}\text { hESC-derived DA neurons transplanted in rhesus monkey resulted in immunogenicity [25]. iPSC } \\
\text { autologous cells immune rejection reported in mouse [28] }\end{array}$ \\
\hline & Disease transmission & $\begin{array}{l}\text { Possibility of pathogens in starting material. The current tests only address a limited number of } \\
\text { pathogens. Risk of BSE is a concern }\end{array}$ \\
\hline & $\begin{array}{l}\text { Unwanted tissue } \\
\text { formation }\end{array}$ & $\begin{array}{l}\text { Precision of brain region in final product administration is required to avoid unwanted tissue } \\
\text { formation }\end{array}$ \\
\hline & Toxicity & Only very low risk of toxicity \\
\hline \multirow{4}{*}{$\begin{array}{l}\text { Cell population heterogeneity } \\
\text { and varied differentiation } \\
\text { capacity }\end{array}$} & Tumor formation & $\begin{array}{l}\text { Undifferentiated cells in final product induce tumor }[29,30] \text {. Enhanced characterization resolved } \\
\text { tumorigenesis by acute differentiation }[19,31]\end{array}$ \\
\hline & $\begin{array}{l}\text { Unwanted } \\
\text { immunogenicity }\end{array}$ & $\begin{array}{l}\text { Abnormal expression of Hormad } 1 \text { and Zg16 contributes to immunogenicity of iPSCs [28] so } \\
\text { heterogeneity may contribute }\end{array}$ \\
\hline & Treatment failure & $\begin{array}{l}\text { Molecular marker expression of the product is not consistent between different processes. Level of } \\
\text { expression is not quantified }\end{array}$ \\
\hline & $\begin{array}{l}\text { Unwanted tissue } \\
\text { formation }\end{array}$ & $\begin{array}{l}\text { Injection of stem cells into brain may cause inflammation and immune rejection. Risk of other tissue } \\
\text { formation }\end{array}$ \\
\hline \multirow[t]{2}{*}{$\begin{array}{l}\text { Growth factors } \\
\text { GDNF, BDNF, Insulin }\end{array}$} & Tumor formation & $\begin{array}{l}\text { GFs may induce tumor formation. Similar protocols used in DA neuron derivation and } \\
\text { transplantation without tumors }[19,21]\end{array}$ \\
\hline & $\begin{array}{l}\text { Unwanted } \\
\text { immunogenicity }\end{array}$ & Possible immune reaction to growth factors \\
\hline \multirow[t]{2}{*}{ Genetic stability } & Tumor formation & $\begin{array}{l}\text { Chromosome aberration results in tumor }[32,33] \text {. Level of stability details obtained is not adequate. } \\
\mathrm{G} \text { banding or ploidy tests are not sufficient but no clear guidelines on the level of details required }\end{array}$ \\
\hline & Treatment failure & Risk of treatment failure. Risk of other tissue formation \\
\hline
\end{tabular}

Table 2. Risks arising from the administration and fate of the product.

\begin{tabular}{|c|c|c|}
\hline Risk factor & Major risks & Evidence and mitigation \\
\hline $\begin{array}{l}\text { Bio distribution as cell suspension } \\
\text { injected }\end{array}$ & Treatment failure & $\begin{array}{l}\text { Bio distribution of injected cells may affect efficacy: Failure to function or survive [34]. Systemic } \\
\text { injection failed to localize to CNS in rodents [35]. DA neuron injection planned for substantia } \\
\text { nigra/striatum in these studies }\end{array}$ \\
\hline \multirow[t]{2}{*}{ Host tissue location precision } & $\begin{array}{l}\text { Unwanted } \\
\text { immunogenicity }\end{array}$ & Transplanted cells were immunogenic [36] \\
\hline & Treatment failure & $\begin{array}{l}\text { Dyskinesias resulted in human fetal neuron transplantation [37]. Injection location-specific effects } \\
\text { reported (striatum/putamen) [36]. Multiple intra-striatal grafts (better) or single intra-nigral } \\
\text { grafts [38]. Simultaneous striatal and intranigral double injection of nigral cells produced better } \\
\text { efficacy [39] }\end{array}$ \\
\hline $\begin{array}{l}\text { Cell preparation and devices to } \\
\text { administer drug product (needle } \\
\text { and aggregated DA neuron } \\
\text { progenitors) }\end{array}$ & Treatment failure & $\begin{array}{l}\text { Single cells/partial suspension of fetus better [40]. Intrastriatal injection of cells grown on gelatine } \\
\text { microcarrier beads survived [41] }\end{array}$ \\
\hline $\begin{array}{l}\text { Biological variation of patients } \\
\text { and patient selection }\end{array}$ & Treatment failure & Only few patients had disease reversal in fetal neuron trial [42] \\
\hline
\end{tabular}

\section{Comparability requirements based on identified risks}

Post-approval changes to the conditions of manufacture that were described in the Chemical, Manufacturing and Controls package must be addressed adequately. The outcome is heavily influenced by the scope of the Comparability Protocol. A Comparability Protocol is a document describing how a future change to a manufacturing process shall be managed and the circumstances under which a reduced reporting category for the change may legitimately be adopted [49]. A 'bridging study' is the investigation required to demonstrate that the change has had no significant impact upon the quality, safety or efficacy of the product. 


\begin{tabular}{|c|c|c|}
\hline Risk factor & Major risks & Evidence and mitigation \\
\hline \multirow[t]{3}{*}{$\begin{array}{l}\text { Extracellular matrix } \\
\text { biological/synthetic }\end{array}$} & Tumor formation & $\begin{array}{l}\text { No feeder cells used. Matrigel (may induce tumor [43]). Gelatine, polyornithine, laminin } \\
\text { and fibronectin were used in the process }\end{array}$ \\
\hline & Unwanted immunogenicity & Experimental evidence showed no immunogenicity [19] \\
\hline & Disease transmission & Possible \\
\hline $\begin{array}{l}\text { Animal model } \\
6 \text { OH DA model is healthy } \\
\text { compared with } \\
\text { neurodegenerating Parkinson } \\
\text { patients }\end{array}$ & Treatment failure & $\begin{array}{l}\text { Models do not fully represent disease condition. Pitx3 ablated (no nigro-striatal } \\
\text { innervation) aphakia mouse model may better represent disease [44]. ES-derived DA } \\
\text { neuron transplantation improves aphakia mouse PD symptoms [45] }\end{array}$ \\
\hline Dosage: how much to inject? & Treatment failure & $\begin{array}{l}\text { Fetal neuron transplantation in humans obtained a proportional clinical improvement to } \\
\text { the size of the transplant [46]. 200K DA neurons in mice as a 2-step sequential injection } \\
2 \text { days apart resulted in better efficacy [47] }\end{array}$ \\
\hline
\end{tabular}

\begin{tabular}{|lll|}
\hline Table 4. & Risk rating categorization table. & \\
\hline Likelihood & Consequence & Risk rate \\
\hline Possible & Major & High \\
\hline Likely & Catastrophic & \\
\hline Almost certain & & Medium \\
\hline Possible & Moderate & \\
\hline Likely & & Low \\
\hline Almost certain & & \\
\hline Unlikely & Minor & \\
\hline Possible & & \\
\hline
\end{tabular}

\begin{tabular}{|c|c|c|c|c|c|c|}
\hline Product dependent risks & $\begin{array}{l}\text { Tumor } \\
\text { formation }\end{array}$ & $\begin{array}{l}\text { Unwanted } \\
\text { immunogenicity }\end{array}$ & $\begin{array}{l}\text { Treatment } \\
\text { failure }\end{array}$ & $\begin{array}{l}\text { Disease } \\
\text { transmission }\end{array}$ & $\begin{array}{l}\text { Unwanted tissue } \\
\text { formation }\end{array}$ & Toxicity \\
\hline Raw material & & & & High & & Medium \\
\hline Starting material & Medium & High & & High & & \\
\hline Growth factor & Medium & & & & & \\
\hline Heterogeneity & Medium & Medium & Medium & & Medium & \\
\hline Genetic stability & High & & High & & & \\
\hline Stage of differentiation & Medium & & Medium & & Medium & \\
\hline Undifferentiated cells in product & High & & High & & High & \\
\hline Biological variability & & & High & & & \\
\hline Patient selection (age, sex, etc.) & & & Medium & & & \\
\hline Bio-distribution & Low & & & & Low & \\
\hline Tissue location precision & Medium & & High & & Medium & \\
\hline Cell preparation method & & & Medium & Low & Medium & \\
\hline Dosage & Low & Low & High & & & \\
\hline
\end{tabular}

For the three processes that we examined, there are several potential changes that may become necessary before human application at commercial scale:

- Changes in starting materials

- Changes in the raw materials

- Replacement of a growth factor

- Changes in grade of cell culture plastics 
Table 6. Risk matrix: process-related risks.

\begin{tabular}{|c|c|c|}
\hline Process related risks & Potential risk & Risk level \\
\hline Cell line variability and need for new cell line & $\begin{array}{l}\text { High input biological variation to process. Comparability issue if } \\
\text { new cell line used }\end{array}$ & High \\
\hline Facility (cell line derivation) qualification qualification/validation & Quality risk & Medium \\
\hline Process length ( $\sim 25$ days) & Control of process, financial risks when batch fails & Medium \\
\hline Critical dose and temporal dependency of growth factors/agents & Risk to control process and growth factor batch variability & Medium \\
\hline $\begin{array}{l}\text { Risky process steps } \\
\text { - Embryoid body } \\
\text { - Passaging }\end{array}$ & Heterogeneity, process control, scale issues & High \\
\hline Specification of surrogate marker expression & Lack of relevance to potency and unknown risk of variation & Medium \\
\hline Lacks intermediate stage characterization & Process control risk, financial risks when batch fails & Medium \\
\hline Lack of intermediate banking or cryopreservation & Process control, financial risks when batch fails & High \\
\hline Drug product formulation & Not addressed at all, substantial changes may occur & High \\
\hline Transportation and stability & Not sufficiently addressed, may affect product stability & Low \\
\hline Drug-delivery system/method & Precise tissue location and tissue damage, IP issues & High \\
\hline Dose & Treatment failure, dyskinesia, unwanted tissue formation & High \\
\hline
\end{tabular}

- The research lines may carry risks from (unproven) transmissible spongiform encephalopathy content and, unless the banks carry satisfactory details about provenance of cell isolates and all medium components, it will become appropriate to rebuild them

- Reprogramming methods can influence the cell quality even when genomic stability and the passage number of the cell line used are held constant

- Manufacturing process may change with improved technology

- Drug Product formulation may vary

- The current processes lacks a cryopreservation step and such a step is likely to be needed for an allogeneic product

- Manufacturing location may change

- Local regulations may affect the operability of the process

A Critical Quality Attribute (CQA) is a property, feature or characteristic of the final product that must be conserved by maintaining process controls within acceptable limits. At present there is a discrepancy in the marker-based CQAs between the processes (see Table 7), reflecting the historical path of research at each site. The measurement method of each of those CQAs is currently qualitative and when we began our work none of the studies to date had addressed quantitatively the effect of variability in the expression levels. In-process measurement of these CQAs therefore warrants early and major investment to assist process control later on. The CQAs mainly indicate the product purity but the profile of impurity and the impact upon efficacy of variation of both purity and impurity profile has to be addressed. A specification must be set on both parameters.

Process length and provenance and security of supply of raw materials are also important early considerations as they can significantly contribute to the process robustness and to the cost of goods. Steps to reduce risks in this area must be considered early in the product development.

In-process measurement offers the potential for real-time release of drug product and must be developed alongside the process if it is to be effective. The strategy for cell banking must be considered during late preclinical development and the size of the banks must be designed in order comfortably to maintain the QTPP. In the research stage processes, cells were differentiated into progenitors and then transplanted into disease models. In any process to deliver cryopreserved drug product this must be augmented with controlled cryopreservation and thaw steps. The viability post-thaw needs to be adequately reproducible.

\section{Tool 3: ECV-based prioritization}

The risk analysis of the differentiation processes identified several key gaps in characterization, process and product knowledge. Any decision to mitigate these gaps requires investment of time and money. The management of intra-project investment resembles the management of a multi-project research portfolio with the difference that study options rather than product options are examined. A decision to make such investment early in the product 


\begin{tabular}{|c|c|c|c|c|}
\hline \multicolumn{2}{|l|}{ Surrogate markers } & \multicolumn{2}{|c|}{ In vitro expression profile from studies } & \multirow{2}{*}{ Method of detection } \\
\hline & Kriks & Kirkeby & Hallett & \\
\hline DA release & +ve & + ve & - & Amperometry, HPLC \\
\hline $\mathrm{TH}+$ & $>75 \%$ & + ve & $7 \%$ & \multirow{16}{*}{$\mathrm{qPCR}$, immunodetection } \\
\hline Girk2 & +ve (5\%) & $+\mathrm{ve}$ & $+\mathrm{ve}$ & \\
\hline DAT & +ve $(5 \%)$ & - & - & \\
\hline EN1 & - & + ve & + ve & \\
\hline FOXA2 & $>80$ & + ve & $<20 \%$ & \\
\hline LMX1 & $>65$ & + ve & - & \\
\hline$\beta$-tubulin & - & - & + ve & \\
\hline CORIN & - & + ve & - & \\
\hline Nurr1 & $>55$ & - & - & \\
\hline OTX2 & $>80 \%$ & - & + ve & \\
\hline TH+/ FOXA2+ & $<20 \%$ & - & $2 \%$ & \\
\hline LMX1+/FOXA2+ & $90 \%$ & $80 \%$ & - & \\
\hline Purity/negative mar & & & & \\
\hline $5 \mathrm{HT}$ (serotonergic) & $2-3 \%$ & - & $1-2 \%$ & \\
\hline GABA & $<5 \%$ & - & - & \\
\hline $\begin{array}{l}\text { Proliferation } \\
\text { PCNA } \\
\text { Ki67 }\end{array}$ & $<1 \%$ & \multicolumn{2}{|c|}{ Progressive reduction } & \\
\hline
\end{tabular}

development lifecycle improves market readiness and commercial viability later on. A quantitative tool is needed and an under-exploited method, normally used for R\&D portfolio management can usefully be applied.

\section{ECV decision tool}

In what follows we examine decision optimization in the given project. Resources are limited; research challenges seldom are. How do we choose which studies to do and when? Strategic choices must be made about how best to deploy R\&D expenditure. However, we may feel good because the projects are progressing well, but 'doing projects right' is not the same thing as 'doing the right projects' [50] and our feelings may be misleading us. Humans are notoriously poor at making decisions based on anything other than the simplest probabilistic concepts [51]. By making use of the technique below we can use the maximization of value at any given present moment to make decisions about priority of research for a process in development.

ECV-based tools have been long-established for the management of R\&D portfolios. Similar methods can be applied in CBMP process research projects because they allow us to balance the investment decisions in the 'development dilemma'.

\section{Key concepts}

'Time-related uncertainty': Any investment becomes less speculative as uncertainty is reduced. The art is therefore to balance the degree of speculative investment against the progressive removal of uncertainty to establish an acceptable trade-off.

'Net Present Value' (NPV): Here the NPV is the value now of a project that will be delivered at some future time. We normalise the time-related value to a common point so that the effects of risk and inflation are removed. The decision usually must be made now, so the present is chosen. An NPV is the payoff discounted to the present using a factor that reflects inflation and the risk-related diminution of value to give a Discounted Cash Flow (DCF). It lumps together the risk factors into one global term. DCF should be used, strictly, only to value assets. An 'options' approach is more suitable for the decision trees typically found in project plans. We can develop this using: 
ECV: The ECV is the expression of the commercial worth of a project or option in the present day and adjusts for risk at a detailed level. It often involves a decision-tree analysis, compounding the effect of risks.

An ECV is commonly used to prioritize projects in a portfolio. The ranking by value is compared with the available resources and a line-draw provides a threshold below which projects are de-selected.

The conventional expression of the ECV is [52]:

$$
E C V=\left(N P V \times P_{C S}-C\right) \times P_{T S}-D
$$

The conventional expression of risk-based ECV, based upon the cost of commercialization and the cost of development, each adjusted for their own respective probability or risk

Where:

$\mathrm{C}=$ Cost of commercialization or launch

$\mathrm{D}=$ Cost of development

$\mathrm{ECV}=$ Expected current calue

$\mathrm{NPV}=$ Net present value

$\mathrm{P}_{\mathrm{CS}}=$ Probability of commercial success

$\mathrm{P}_{\mathrm{TS}}=$ Probability of technical success

We can manage the research using simple risk models based upon the project plan. This approach takes as its tenets the ideas that each study allows a decision to be made. We can represent the outcome of each activity as a milestone with a probability-weighted outcome as a decision point. The possible outcomes at any one time may then be calculated as a cumulative probability across the paths that determine that decision tree. Each time a study is concluded the calculation is repeated. This technique shows the progressive increase in the value of the project(s) over time. The gradient of maximum rate of value increase can be used to prioritize research decisions and may be modified by strategic or political issues.

This tool was developed by the research management theorist F Peter Boer [53]. Boer's insight brings an important perspective to what had formerly been an art by assigning value to the option to abandon i.e. it includes the 'opportunity cost' of a course of action in the calculation. Competitive advantage will vest in researchers who collect information from past projects that allows them the most accurate predictive skill.

The concept is relevant to CBMPs at their current stage of process knowledge because of the relative absence of information on the process capability at each step. An organization that builds a re-usable library of such data will gradually be able to rely more on rules of thumb than this more model-based approach.

The value of the approach is best considered by applying it in the context of an illustration from the Project. In Figure 2 there is a choice: whether to prioritize research on the efficacy or research on the manufacturing route. We can represent this choice with some very broad scoping estimates as shown in Figure 7.

The possibility that either the manufacturing research or the in vivo work may lead to project failure represents a 'unique risk' for the project; that is to say, it is a risk inherent in the work and does not rely on external influences. In order to make a decision with confidence based solely on the unique risk it is best to quantify the cumulative risk for each of the alternative courses of action. The decision points can be represented using a 'Decision Tree', in effect a quantitatively-loaded version of Figure 2.

By contrast, the quantification of the costs of the research choices and their prioritization can be done using a 'Real Options' approach [54,55]. This is based on the observation that the future decision whether or not to invest at a decision point depends on the discounted value of the project at that time weighed against the cost to reach that point. This approach has traditionally been divorced from the Decision Tree method because it is calculated using 'market risk' i.e. risk that, unlike 'unique risk', cannot be mitigated by diversification. However, as Boer points out [53] the combination is possible and legitimate because project plans represent, in effect, a series of options with the ability to proceed or to withdraw at each phase.

Following Boer's description the approach can be depicted as a series of steps that are illustrated here for our example. In these illustrations the costs given and the value to be realized are hypothetical. This is for two reasons. Firstly the instances of cost and value for a PD product are commercially-sensitive data. Secondly the values used are to make the decision points clear in a way that would be obscured by a calculation with many more layers and more nuanced costs. 


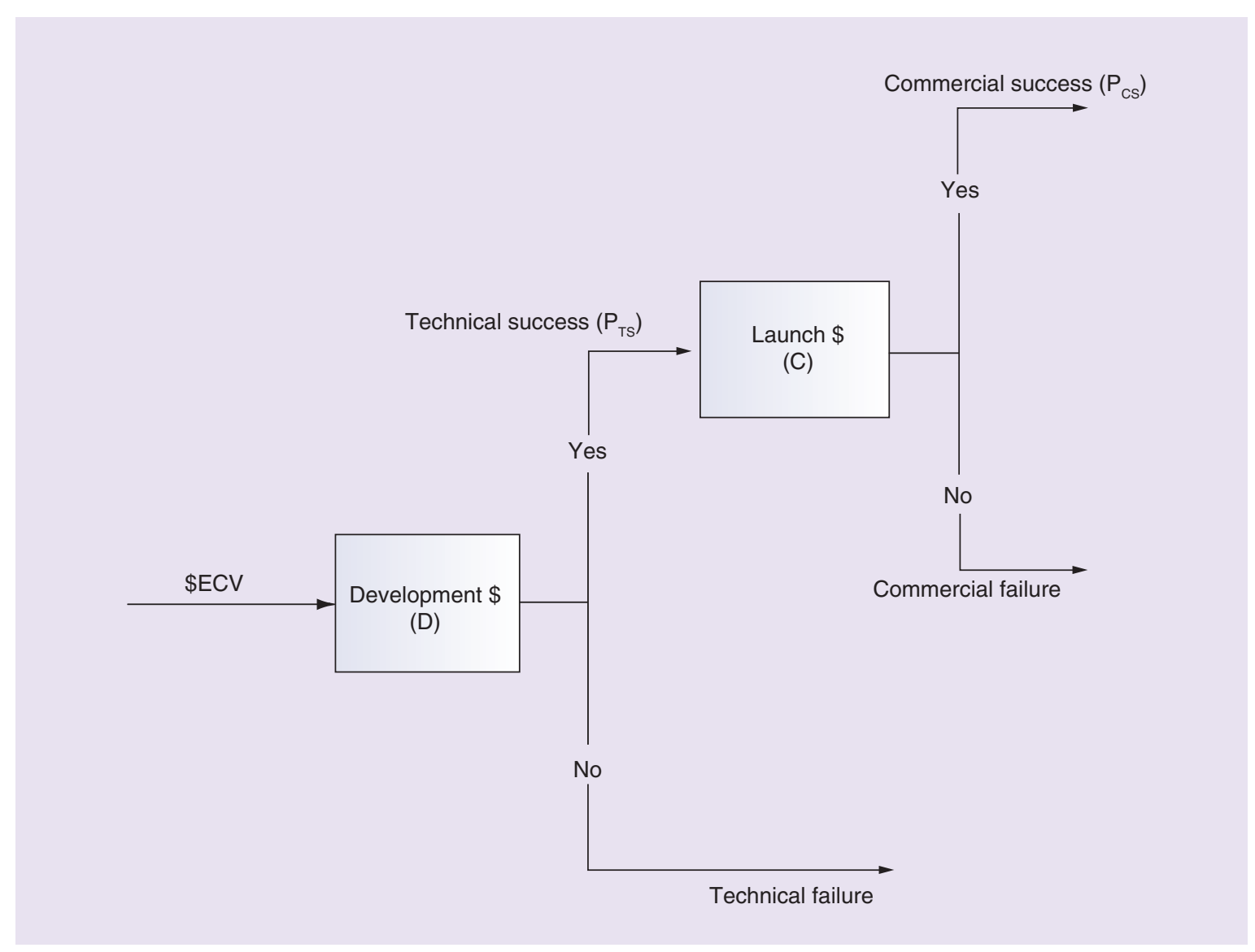

Figure 7. Expected current value decision tool. The ECV is based on the probability of technical success and the probability of commercial success assuming that the product can be launched.

C: Cost of commercialization or launch; D: Cost of development; ECV: Expected current value; $P_{C S}$ : Probability of commercial success; $P_{\mathrm{TS}}$ : Probability of technical success.

\section{Case 1: prioritize efficacy}

Step 1: organizing the calculation

Three inputs are needed: the risk-free interest rate and the cost of capital (the discount rate) are represented for convenience here by the values of $5 \%$ and $12 \%$ as in Boer's published work. The third input, the 'volatility' in the market influence, is needed to deal with the options part of the model and this aspect can preferably be regarded as the 'volatility of the cash margin of the product to which the business plan is linked' [53]. This will be familiar to researchers in advanced therapy manufacture as the margin arising from the uncertainty surrounding the reimbursement model versus the uncertainty in the cost of goods calculation.

For simplicity let us assume that, on completion of the process research, the deployment of the technology to the launch site will cost $\$ 3$ million. The present value of the project is shown by the sum of the NPV and the initial investment.

In practice if an organization were to follow the approach in our example then a prudent course of action would be to perform sensitivity calculations on the result in order to show the extent to which the outcome is influenced by small changes in the basic assumptions.

The NPV is referred to the beginning of the commercialization phase. However, to regard the commitment of all research costs as a single figure is to disregard the value of the ability to abandon the project if required at appropriate phase-gates, thus saving further commitment. This is where the Decision-Tree calculation comes into play.

Each phase of the project comprises a series of activities. The duration, probability of success and discounted cost of each activity up to launch are placed in a simple spreadsheet-based model. In the example of Figure 2 we 
see two main activities (process research and in vivo trials) and two other activities (develop comparability protocol and conduct bridging studies) that are associated with pursuing the in vivo study as a priority.

The probability of success is estimated and the confidence of the estimate will improve to an extent over time as the organization encounters similar steps in successive projects.

In our illustration (greatly simplified from the real case) there is an assigned NPV of $\$ 3$ million upon launch. This is realized in year 4 if the in vivo trials (efficacy) are prioritized.

Step 2: calculation

Decision-tree only approach

The valuation, making use of the cost of abandonment, is calculated as the sum of the probability-weighted value and cost of each branch of the Decision Tree. For the case where efficacy is prioritized the result is:

$$
=\sum \text { Values } \times \text { Probabilities }
$$

Calculation of the probability-weighted value of each branch of the Decision Tree is based upon the cumulative costs for that branch adjusted using the cumulative probability of success for that branch. Each branch represents a possible outcome of the process development stage.

$$
\begin{aligned}
& =(\text { Risk }- \text { adjusted value of arm to exploitation }) \\
& -(\text { Cost of abandonment at year } 4) \\
& -(\text { Cost of abandonment at year } 3) \\
& =\$ 86,038-\$ 199,945-\$ 310,1268=(\$ 424,174)
\end{aligned}
$$

Note that failure to include the option to abandon gives a valuation of

$$
=\$ 285,983-\$ 1,332,965=(\$ 1,046,982)
$$

The result, in this case, is not attractive either with, or without, the option to abandon although the exclusion of the option to abandon results in a far less attractive value.

\section{Decision-tree \& real option approach}

The 'market risk' can now be factored in i.e. the uncertainty that arises from features of the market opportunity and our limited knowledge of it.

This alternative viewpoint consists of framing the project as a series of investment decisions, one at each decision point. To derive a quantitative comparison we must work back from realization of value at launch to the present moment, using the project value subsequent to each point as the value that may be realized by exercising the decision or 'option' that precedes it.

The decision at year 4 to deploy to launch is a 'real option' to invest $\$ 3$ million (the 'exercise price' or 'strike price') in addition to the value of the successful project, i.e. the present value, at the time of the decision, or 'underlying security' (the 'stock price') for the option. Using the DCF method this is:

$$
D C F=\frac{\text { Investment at decision point }}{\text { Discount factor } \left.{ }^{(\text {Years }} \text { to decision }\right)}+\text { Value release }
$$

Discounted Cash Flow can be used to express the balance of value at the present time of a decision to pursue a positive course of action at each decision point in the Decision Tree.

$$
=\frac{\$ 3 M}{(1.05)^{4}}+\$ 1.907 M=\$ 4.375 M
$$


In order to include the impact of volatility, the value of this option over the year 3-4 is calculated using the Black-Scholes model at a market volatility of $50 \%$. The basis of the calculation and user-friendly tools to calculate it are widely available. Here we use a popular online tool [56] to give $\$ 2.011 \mathrm{M}$. Adjusted for the probability of success ( $50 \%$ of this arm) the value of the option becomes $\$ 1.006$ million.

The value of $\$ 1.006$ million is the underlying security or 'stock price' for the first decision point. We can now work back to that previous decision point which is the call option at the end of year 2 to spend $\$ 1.250$ million on process research in years 3 and 4 , by using a strike price for the option equal to the cost of the next stage or research investment discounted to that decision point at the risk-carrying rate (as experimental work is involved) of $12 \%$.

$$
=\frac{\$ 500 k}{(1.12)^{3}}+\frac{\$ 750 k}{(1.12)^{2}}=\$ 953 k
$$

The Black-Scholes calculation returns $\$ 336 \mathrm{k}$ and, allowing for a $30 \%$ probability of success at this decision point, the value becomes $\$ 101 \mathrm{k}$. The discounted cost of reaching this point is the sum of the first two years of research $(\$ 443,240)$ so the project as a whole has a negative value $(\$ 342 \mathrm{k}$; Figure 8$)$.

\section{Case 2: prioritize process}

We now turn our attention to the alternative, which is to place more confidence in a positive outcome to the efficacy studies and to absorb early the costs of process development work instead. This is not a straightforward comparison because the cost of performing comparability studies is largely removed. In the real case there will still be work to do on the comparability protocol but in our example we simplify by omitting it. We continue with the same values for the risk-free interest rate, the cost of capital and the 'volatility'.

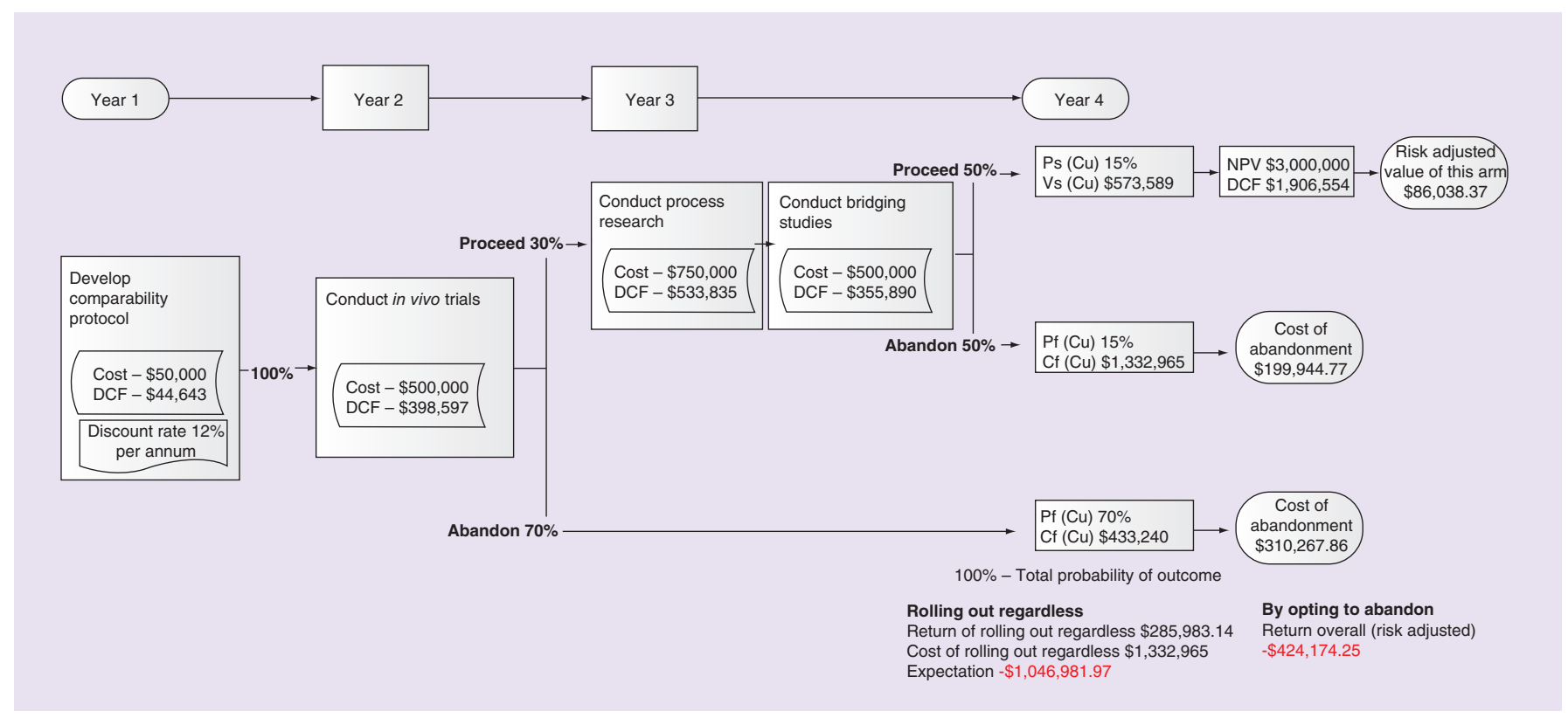

Figure 8. Expected current value calculation based on 'Prioritize efficacy' route. The Figure illustrates the steps involved in the ECV calculation at an annual discount rate of $12 \%$. A representative time frame required for the development is shown in the top panel indicated in years. A well-designed comparability protocol is a critical prerequisite in this route of development. Dependent on the data available from in vivo studies, a choice can be made to abandon the development ( $70 \%$ probability) or to proceed with further process development and bridging studies ( $30 \%$ probability in this case). At the later stage of the development a further $50 \%$ probability exists for failure. This adds to the early-stage abandonment probability of $70 \%$ and results in a cumulative $85 \%$ probability for failure. Cf: Cost to failure; 'Cu': Cumulative; DCF: Discounted cash flow; NPV: Net present value; $\mathrm{P}_{\mathrm{f}}$ : Probability of failure; $\mathrm{P}_{\mathrm{s}}$ : Probability of success; Vs: Value if successful. 


\section{Decision-tree only approach}

$$
=\sum \text { Values } \times \text { Probabilities }
$$

Calculation of the probability-weighted value of each branch of the Decision Tree.

$$
\begin{array}{r}
=(\text { Risk }- \text { adjusted value of arm to exploitation }) \\
-(\text { Cost of abandonment at year } 3) \\
=\$ 320,130-\$ 747,768=(\$ 427,638)
\end{array}
$$

Note that failure to include the option to abandon gives a different level of valuation than in the first case. This is due to the smaller influence of avoiding incurred development costs for the whole project than is the case above.

$$
=\$ 640,602-\$ 1,068,240=(\$ 427,638)
$$

Once more the result is not attractive either with, or without, the option to abandon.

\section{Decision-tree \& real option approach}

The decision to deploy at year 3 is valued at (with reference to Equation 3):

$$
=\frac{\$ 3 M}{(1.05)^{3}}+\$ 2,135 M=\$ 4.727 M
$$

Calculation of the value of launch taking into account the discounted investment and the discounted value released. Note that each component bears a different discount factor.

The value of this option over the year 2-3 is once more calculated using the Black-Scholes model at a market volatility of $50 \%$ and a cost to exercise (the launch cost) of $\$ 3$ million. The decision to launch is here only one year from the previous decision. Here the model returns a value of $\$ 2.020$ million which, adjusted for the probability of success ( $30 \%$ of this arm) becomes $\$ 0.606$ million.

In this case there is no previous decision point and the discounted cost of reaching this decision point is the sum of the first two years of research $(\$ 1,068,240)$ so the project as a whole has a negative value $(\$ 462,240)$ Figure 9 .

\section{Discussion}

The 'development dilemma' in CBMP process design illustrates the importance of a systematic approach to management of risk, investment and sequence of studies for an area where the body of process knowledge is not as extensive as it is in, say, pharmaceutical chemical engineering. Product complexity means that improved characterization of the product and intermediates is valuable. This comes at the expense of time and money. The tools illustrated here gave guidance to the UKRMP Team in terms of area of research focus and prioritization of topics. The NPI map emphasizes development and characterization requirements relevant to the each stage of the process development (i.e., when to do the work). This tool, in combination with the risk assessment, identified existing gaps in product knowledge (i.e., what work to do). Net commercial value generation of such development can be assessed with ECV method presented (i.e., whether to do the work and in what order).

In this example, genetic stability and tumorigenesis, the development of an intermediate-stage product and formulation are the key areas for further research.

\section{Genetic stability \& tumorigenesis}

Studies show that different culture conditions affect the genetic stability of hESCs and the exact causes may be hard to identify. Significant advances have been made in the maintenance of stem cells in culture with replacement of animal-derived feeder cell layers and the replacement of serum with defined medium. Even with such improvements, stem cell culture practice still suffers from incidences of karyotype abnormality in culture [57]. Advanced analytical techniques show that enzymatic passaging and nonfeeder matrices may affect the karyotype and gene expression 


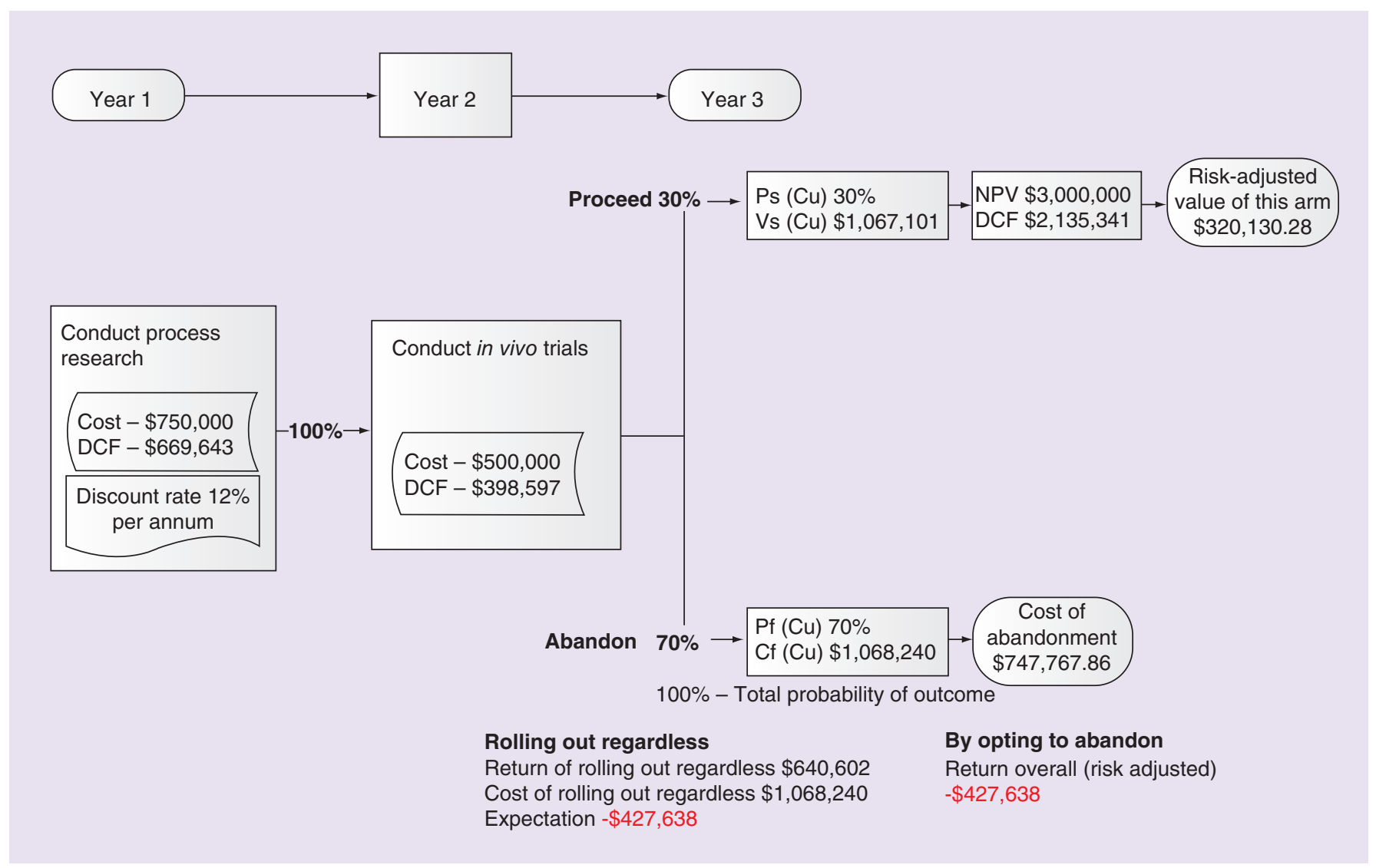

Figure 9. Expected current value calculation based on 'Prioritize process' route. This figure illustrates the expected current value calculation method when the process-prioritized route is chosen. Early process research followed by in vivo studies generates a $30 \%$ probability to proceed with the development and a $70 \%$ probability to abandon further development. Significant increase in the cumulative value $(\$ 1,067,101)$ is obtained in this route.

Cf: Cost to failure; 'Cu': Cumulative; DCF: Discounted Cash Flow; NPV: Net Present Value; Pf: Probability of failure; Ps: Probability of success; $V_{s:}$ Value if successful.

profile of stem cells [58]. Such culture conditions were reported to have deleterious effects on chromosome stability and copy number variation within five passages [59]. Other studies found no difference between enzymatic and mechanical passaging [60]. Recent work from the iPSC-based trial for age-related macular dystrophy at the RIKEN institute came to a halt due to potentially carcinogenic mutations [61]. hESC-derived neural progenitor cells injected into rat brain resulted in PSCs remaining and also caused teratocarcinoma-related premature death in some animals [29]. A patient injected with neural stem cells was reported to form brain tumor after a few years of treatment [62]. From a screen of 140 independent hESC lines, the extent of the mutations in the TP53 gene that potentially cause cancer was revealed [63]. Different types of mutations and genetic changes to the cell lines make them more susceptible to develop cancer [64]. The expansion and differentiation process is not standardized in the protocols in our study and they are subject to high levels of operator discretion. As the evidence suggests that the presence of genetically unstable cells may cause tumors [65] it is appropriate to include studies to identify and control physicochemical features of the culture conditions that affect genetic stability and resultant tumorigenesis.

\section{Hold steps}

The process of DA differentiation is longer than that presented in Figure 4 as the initial expansion of hESCs prior to differentiation is not represented. From a thawed hESC vial it may take several passages to obtain a culture with stable growth rate (unpublished data). Taking into consideration the duration of initial expansion the whole process may exceed six weeks. From a GMP perspective this is challenging to manage and the introduction of a hold step would reduce the risk considerably. As indicated in Figure 1, introduction of a cryopreservation step would facilitate the process. Cryopreservation of neural progenitors with capacity to differentiate into GABAergic neurons 
has been shown to maintain viability and differentiation potential [66]. Although not identical to the manufacture of neural progenitor cells [67], this study suggests that a population of neural precursor cells can be generated and maintained for several passages before differentiating into DA neurons [68].

\section{Formulation}

In the preclinical studies described in this article, drug substance (differentiated DA progenitor neurons) was suspended in cell culture media or PBS $[19,45,46]$ or in HBBS prior to transplantation [69]. Inclusion of a cryopreservation and thawing step for the formulated drug product would allow the distribution of drug product manufactured centrally to the point of administration. Some studies have examined ways of cryopreserving neural progenitors without compromising quality. Mouse neural progenitors cryopreserved in differentiation medium with $10 \%$ DMSO maintained viability and differentiation potential [70]. A recent study using mouse DA neurons cryopreserved in DMSO- or glycerol-containing agent showed that these did not adversely affect the quality of the cells [71]. Another study proved that cryopreservation of human iPSC-derived DA neurons did not adversely affect product quality. Cryopreserved cells maintained high viability and molecular marker expression profiles compared with non-cryopreserved cells [72].

The principles described in this paper may be extended, with care, to other categories of pluripotent stem cell therapies. Two examples will illustrate this point.

iPSC-derived cardiomyocytes [73] as an autologous cell source for myocardial repair also require robust preclinical and clinical evidence in order to provide a safe and reproducible product. Just as for PD treatment the product will require a uniform cell sub-type that is free from tumorigenic cell contaminants. In this case it is especially important that the cell functionality, survival post-engraftment and behavior as an adult cell are adequate. The intrinsic variability of the source material for what is likely to be an autologous therapy, is an additional and somewhat different hurdle and would require a carefully-justified qualification of prospective patients in addition to the considerations for PD in order to avoid straying beyond the parameters that are accommodated in the control strategy.

By contrast iPSC-derived cells for use in conditions such as degradation of diarthrodial joints by arthritis may, in the case of hyaline cartilage at least, be feasible from an allogeneic cell bank but in this case the design of the process may progress through mesenchymal stem cell banks as therapeutic intermediates in order to avoid the heterogeneity that will otherwise attend attempts to differentiate directly to, for example, chondroprogenitors of predictable efficacy [74].

\section{Conclusion}

The research and investment needed to produce safe, economic, reproducible and operable manufacturing processes for novel cell-based therapies is significant. The research community has found its own, often local, methods for addressing priority for studies and for making decisions about when and how to address the features of the process that exert the most influence over product properties.

We offer a set of three interrelated tools that have found value in the UK Regenerative Medicine Platform project where we have applied them to the process design for neuroprogenitors. As the research community adds to its knowledge base we look forward to a time when the insights gained will permit faster and more accurate planning and execution of process studies based upon increasing levels of confidence in estimation of time, cost and probability of success of process design studies.

The overarching priority for the sector is the generation of succinct, effective, capable processes. Using the approach described above the research team was able to reduce the considerable detail within the existing protocols to a concise process manufacturing instruction that captured the constraints that were necessary to manage the process features that exert the most influence. The key attribute of effective technology transfer documents between sites, personnel and programmes is, in our experience, this brevity and focus. Its achievement requires a systematic and robust methodology that focuses time and resource on a hierarchy of research priorities.

\section{Future perspective}

It is a commonplace observation in the development of medicinal products that the first entrant to market for a treatment obtains $80 \%$ of the market share or better and that this dominant position is difficult for later entrants to displace. As a result the race to shorten development times and to maximize the value of the resources deployed is a deciding factor in commercial success. We expect two main trends to emerge in the development of cell-based 
therapies over the next 5-10 years. Both relate to the avoidance of unnecessary use of time and money. The first relates to scaling up and is the reduction in the rate of attrition of candidate products between discovery and launch. In order for an organization to have confidence in its pipeline of candidates and to minimize the number that are abandoned in development there must be an accurate reflection of the 'at launch' process and supply chain during the proof of concept studies. Without this insight there is a risk that unforeseen constraints during manufacture at large scale will cause the process features that exert the most influence over product properties to impact on the efficacy and safety of the product, causing a loss of comparability. In order to reduce this risk to an acceptable minimum there must be a growing insight, and preferably a library of studies of the relevant process unit steps, that will enable the process engineers to focus on the features most likely to exert that influence. The second trend applies to those processes that are best scaled out i.e. performed in multiple parallel batches at small scale. Here it will be important to map, characterize and design out the process features that introduce unwanted variation in the control strategy. These features may be human, instrumental or environmental. Full automation may be an unsustainable cost for these largely manual processes and we expect to see the emergence of ergonomically-designed mechanical aids to processing that assist reproducible manipulation through control of timing, materials handling and dispensing and temperature. This trend to mechanization, similarly to the characterization of the unit steps in scaling up, will inform the work of the inventing biologists, becoming part of the vocabulary and sometimes the bench equipment, of the front-end scientists.

\section{Financial \& competing interests disclosure}

This study was conducted under the UK Regenerative Medicine Platform as part of the work of the Cell Behaviour, Differentiation and Manufacturing Hub. It comprised part of the Pluripotent Stem Cell Platform (PSCP) project funded by the Medical Research Council, the Biotechnology and Biological Sciences Research Council and the Engineering and Physical Sciences Research Council (grant number MR/L012537/1). Professor Nicholas Medcalf was funded by the Engineering and Physical Sciences Research Council (grant number EP/K037099/1). The authors have no other relevant affiliations or financial involvement with any organization or entity with a financial interest in or financial conflict with the subject matter or materials discussed in the manuscript apart from those disclosed.

No writing assistance was utilized in the production of this manuscript.

\section{Open access}

This work is licensed under the Creative Commons Attribution 4.0 License. To view a copy of this license, visit http://creativecomm ons.org/licenses/by/4.0/

\section{Executive summary}

- In order to ensure market launch as quickly as possible and with judicious outlay, the process developer must reconcile two opposing needs. To ensure comparability of manufacturing process at commercial scale there must be manufacturing research sufficient to satisfy the 'Chemical, Manufacturing and Control' section of the regulatory application dossier. This must occur at a stage in the project cycle early enough to avoid unnecessary process re-engineering late in development. However, by no means all candidate products succeed at clinical trial and it is desirable to avoid spending money unnecessarily on process research for these putative products. The dilemma can be addressed through the careful use of three decision-making tools. The tools are illustrated in this paper using a case study of a treatment for Parkinson's disease.

The tools that were applied

Tool 1: new product introduction map

- The tool allows the examination of the decision points in the context of the overall product development.

Tool 2: risk-based approach

- A development of the normal requirement for product and process risk analysis, this tool identifies the topics that warrant focused attention.

Tool 3: expected current value-based prioritization

- A project-specific modification of a portfolio-balancing tool, this tool allows decisions about timing of investment to be made on a quantitative basis.

Case study: Parkinson's disease

- Parkinson's disease (PD) is a debilitating condition that is costly to manage and control. It is of growing importance as the average age of citizens in the developed world increases. 
Developing cell-based medicinal products for PD

- The characteristics of a cell-based therapeutic product candidate for PD are discussed in the context of a specific project within the UK Regenerative Medicine Platform programme.

Dopaminergic neuron process description

- The overall process is described and the challenges are described that arise from the need to 'freeze' the process as early as possible in a form in which the product can be made at scale to a predictable and acceptable specification. Two situations are used to show how a value-based development decision may be made: one based upon prioritizing early evidence of efficacy and the other based upon prioritizing the early evidence of process capability.

Discussion

- The application of the tools described in this paper is considered in the context of management of risks to the patient that will otherwise arise. The potential for realization of the risks is illustrated with reference to the known behavior of embryonic and induced pluripotent stem cells.

Conclusion

- The importance of brevity and focus in process development for advanced therapies is re-emphasized and the application of the tools described is placed in that context.

Future prospects

- The future of cell therapy manufacture is likely to be divided between products that require up- or out-scaling for manufacture. Robust process characterization is essential for both yet the features of the process that are relevant may differ between the two categories. Both need systematic assessment. Over time, a growing familiarity with effective techniques for focused process research coupled with a growing library of case studies will empower the user community.

\section{References}

1. Yamanaka S, Takahashi K, Francisco S. The stem-cell revolution is coming - slowly. New York Times. 16 January 2017. https://mobile.nytimes.com/2017/01/16/science/shinya-yamanaka-stem-cells.html

2. Coghlan, A. Mutation alert halts stem cell trial to cure blindness. New Scientist (2015). www.newscientist.com/article/mg22730334-900-mutation-alert-halts-stem-cell-trial-to-cure-blindness/

3. Medcalf N. Chapter 12 - Business models for manufacture of cellular therapies. In: Stem Cell Manufacturing. Cabral JMS, de Silva CL, Chase LG, Margarida Diogo M. (Eds). Elsevier, Oxford, UK, 265-290 (2016).

4. Connolly BS, Lang AE. Pharmacological treatment of Parkinson disease: a review. JAMA 311, 1670-1683 (2014).

5. Moldovan AS, Groiss SJ, Elben S, Südmeyer M, Schnitzler A, Wojtecki L. The treatment of Parkinson's disease with deep brain stimulation: current issues. Neural Regen. Res. 10, 1018-1022 (2015).

6. Das GD, Altman J. Transplanted precursors of nerve cells: their fate in the cerebellums of young rats. Science 173, 637-638 (1971).

7. Lindvall O, Rehncrona S, Brundin P et al. Human fetal dopamine neurons grafted into the striatum in two patients with severe Parkinson's disease. A detailed account of methodology and a 6-month follow-up. Arch. Neurol. 46, 615-631 (1989).

8. Freed CR, Breeze RE, Rosenberg NL et al. Transplantation of human fetal dopamine cells for Parkinson's disease. Results at 1 year. Arch. Neurol. 47, 505-512 (1990).

9. Thomson JA, Itskovitz-Eldor J, Shapiro SS et al. Embryonic stem cell lines derived from human blastocysts. Science 80, 282 (1998).

10. Takahashi K, Tanabe K, Ohnuki M et al. Induction of pluripotent stem cells from adult human fibroblasts by defined factors. Cell 131, 861-872 (2007).

11. Reubinoff BE, Pera MF, Fong CY, Trounson A, Bongso A. Embryonic stem cell lines from human blastocysts: somatic differentiation in vitro. Nat. Biotechnol. 18, 399-404 (2000).

12. Garitaonandia I, Gonzalez R, Christiansen-Weber T et al. Neural stem cell tumorigenicity and biodistribution assessment for Phase I clinical trial in Parkinson's disease. Sci. Rep. 6, 34478 (2016).

13. BioSpectrum. China to conduct first human trials on embryonic stem cells. (2017) www.biospectrumasia.com/news/36/9011/china-to-conduct-first-human-trials-on-embryonic-stem-cells.html

14. Studer L. Strategies for bringing stem cell-derived dopamine neurons to the clinic-The NYSTEM trial. Prog. Brain Res. 230, 191-212 (2017).

15. Kirkeby A, Parmar M, Barker RA. Strategies for bringing stem cell-derived dopamine neurons to the clinic. Prog. Brain Res. 230, 165-190 (2017).

16. Takahashi J. Strategies for bringing stem cell derived dopamine neurons to the clinic. Prog. Brain Res. 230, 213-226 (2017).

17. Kirkeby A, Grealish S, Wolf DA et al. Generation of regionally specified neural progenitors and functional neurons from human embryonic stem cells under defined conditions. Cell Rep. 1, 703-714 (2012). 
18. Grealish S, Diguet E, Kirkeby A et al. Human ESC-derived dopamine neurons show similar preclinical efficacy and potency to fetal neurons when grafted in a rat model of Parkinson's disease. Cell Stem Cell 15, 653-665 (2014).

19. Kriks S, Shim JW, Piao J et al. Dopamine neurons derived from human ES cells efficiently engraft in animal models of Parkinson's disease. Nature 480, 547-551 (2011).

20. Hallett PJ, Deleidi M, Astradsson A et al. Successful function of autologous iPSC-derived dopamine neurons following transplantation in a non-human primate model of Parkinson's disease. Cell Stem Cell 16, 269-274 (2015).

21. Ye J, Bates N, Soteriou D et al. High quality clinical grade human embryonic stem cell lines derived from fresh discarded embryos. Stem Cell Res. Ther. 8, 128 (2017).

22. Chapman J, Greene O, Rhodes W, Zimmerman J. Novartis exploring boundaries of biotech manufacturing and control to make cell and gene therapy commercialization a reality. International Pharmaceutical Quality, Monthly Update - March 2015. 6(2), 3-12 (2015). www.ipqpubs.com/wp-content/uploads/2015/05/IPQ-Monthly-Update-March-2015.pdf.

23. Hentze H, Soong PL, Wang ST, Phillips BW, Putti TC, Dunn NR. Teratoma formation by human embryonic stem cells: evaluation of essential parameters for future safety studies. Stem Cell Res. 2, 198-210 (2009).

24. Kim JH, Auerbach JM, Rodríguez-Gómez JA et al. Dopamine neurons derived from embryonic stem cells function in an animal model of Parkinson's disease. Nature 418, 50-56 (2002).

25. Emborg ME, Zhang Z, Joers $\mathrm{V}$ et al. Intracerebral transplantation of differentiated human embryonic stem cells to hemiparkinsonian monkeys. Cell Transplant. 22, 831-838 (2013).

26. Sundberg M, Bogetofte $\mathrm{H}$, Lawson $\mathrm{T}$ et al. Improved cell therapy protocols for Parkinson's disease based on differentiation efficiency and safety of hESC-, hiPSC-, and non-human primate iPSC-derived dopaminergic neurons. Stem Cells 31, 1548-1562 (2013).

27. English K, Wood KJ. Immunogenicity of embryonic stem cell-derived progenitors after transplantation. Curr. Opin. Organ Transplant. 16, 90-95 (2011).

28. Zhao T, Zhang ZN, Rong Z, Xu Y. Immunogenicity of induced pluripotent stem cells. Nature 474, 212-215 (2011).

29. Roy NS, Cleren C, Singh SK, Yang L, Beal MF, Goldman SA. Functional engraftment of human ES cell-derived dopaminergic neurons enriched by coculture with telomerase-immortalized midbrain astrocytes. Nat. Med. 12, 1259-1268 (2006).

30. Sonntag KC, Pruszak J, Yoshizaki T, van Arensbergen J, Sanchez-Pernaute R, Isacson O. Enhanced yield of neuroepithelial precursors and midbrain-like dopaminergic neurons from human embryonic stem cells using the bone morphogenic protein antagonist noggin. Stem Cells 25, 411-418 (2007).

31. Hallett PJ, Cooper O, Sadi D, Robertson H, Mendez I, Isacson O. Long-term health of dopaminergic neuron transplants in Parkinson's disease patients. Cell Rep. 7, 1755-1761 (2014).

32. Hielscher A, McGuire T, Weisenburger D, Sharp JG. Matrigel modulates a stem cell phenotype and promotes tumor formation in a mantle cell lymphoma cell line. Stem Cell Discov. 3, 167-179 (2013).

33. Andrews PW, Matin MM, Bahrami AR, Damjanov I, Gokhale P, Draper JS. Embryonic stem (ES) cells and embryonal carcinoma (EC) cells: opposite sides of the same coin. Biochem. Soc. Trans. 33, 1526-1530 (2005).

34. Yang S, Lin G, Tan YQ et al. Tumor progression of culture-adapted human embryonic stem cells during long-term culture. Genes Chromosomes Cancer 47, 665-679 (2008).

35. Park CH, Minn YK, Lee JY et al. In vitro and in vivo analyses of human embryonic stem cell-derived dopamine neurons. J. Neurochem. 92, 1265-1276 (2005).

36. Payne NL, Sun G, Herszfeld D et al. Comparative study on the therapeutic potential of neurally differentiated stem cells in a mouse model of multiple sclerosis. PLoS ONE 7, e35093 (2012).

37. Brundin P, Strecker RE, Widner H et al. Human fetal dopamine neurons grafted in a rat model of Parkinson's disease: immunological aspects, spontaneous and drug-induced behaviour, and dopamine release. Exp. Brain Res. 70, 192-208 (1988).

38. Hagell P, Piccini P, Björklund A et al. Dyskinesias following neural transplantation in Parkinson’s disease. Nat. Neurosci. 5, 627-628 (2002).

39. Goren B, Kahveci N, Eyigor O, Alkan T, Korfali E, Ozluk K. Effects of intranigral vs intrastriatal fetal mesencephalic neural grafts on motor behavior disorders in a rat Parkinson model. Surg. Neurol. 64(Suppl. 2), S33-S41 (2005).

40. Mendez I, Baker KA, Hong M. Simultaneous intrastriatal and intranigral grafting (double grafts) in the rat model of Parkinson's disease. Brain Res. Brain Res. Rev. 32, 328-339 (2000).

41. Rath A, Klein A, Papazoglou A et al. Survival and functional restoration of human fetal ventral mesencephalon following transplantation in a rat model of Parkinson's disease. Cell Transplant. 22, 1281-1293 (2013).

42. Stover NP, Bakay RAE, Subramanian T et al. Intrastriatal implantation of human retinal pigment epithelial cells attached to microcarriers in advanced Parkinson disease. Arch. Neurol. 62, 1833-1837 (2005).

43. Moon J, Lee HS, Kang JM et al. Stem cell grafting improves both motor and cognitive impairments in a genetic model of Parkinson's disease, the aphakia (ak) mouse. Cell Transplant. 22, 1263-1279 (2013). 
44. Chung S, Moon J, Kim KS. Improvement of neurological dysfunctions in aphakia mice, a model of Parkinson's disease, after transplantation of ES cell-derived dopaminergic neuronal precursors. Methods Mol. Biol. 1213, 285-291 (2014).

45. Olanow CW, Goetz CG, Kordower JH et al. A double-blind controlled trial of bilateral fetal nigral transplantation in Parkinson's disease. Ann. Neurol. 54, 403-414 (2003).

46. Kopyov OV, Jacques DS, Lieberman A, Duma CM, Rogers RL. Outcome following intrastriatal fetal mesencephalic grafts for Parkinson's patients is directly related to the volume of grafted tissue. Exp. Neurol. 146, 536-545 (1997).

47. Büchele F, Döbrössy M, Hackl C, Jiang W, Papazoglou A, Nikkhah G. Two-step grafting significantly enhances the survival of foetal dopaminergic transplants and induces graft-derived vascularisation in a 6-OHDA model of Parkinson's disease. Neurobiol. Dis. 68, 112-125 (2014).

48. Department of Health. HPSS Guidance on analysis of risk and risk rating matrix (2002). www.health-ni.gov.uk/sites/default/files/publications/dhssps/Guidance on Analysis of Risk.pdf

49. American Association of Blood Banks. Comparability Protocol Resource (2008). www.aabb.org/advocacy/regulatorygovernment/bla/Documents/blacpresourcev1.pdf

50. Cooper RG, Edgett SJ, Kleinschmidt EJ. Portfolio management: fundamental to new product success. PDMA Toolb. New Prod. Dev. 331-364 (2002).

51. Taleb NN. Fooled by Randomness: The Hidden Role of Chance in Life and in the Markets. Texere, London, UK (2001).

52. Klastorin T. Project Management: Tools and Tradeoffs. John Wiley, NY, USA (2004).

53. Boer FP. Risk-adjusted valuation of R\&D projects. Res. Technolog. Management 46(5), 50-58 (2003).

54. Luo L, Sheu H. The real R\&D options value incorporating technological risk management. Kybernetes 39, 770-785 (2010).

55. Kennedy M, Harris C, MacRae A. Risk-weighted cash flow: a communication tool for engineers and financial professionals on new technology projects. CIM J. 3(4) (2012).

56. myStockOptions.com Black-Scholes Calculator. (2019)

www.mystockoptions.com/black-scholes.cfm?ticker $=\& s=6442 \& \mathrm{x}=5000 \& \mathrm{t}=2 \& \mathrm{r}=5 \% 25 \& \mathrm{v}=50 \% 25 \&$ calculate=Calculate

57. Garitaonandia I, Amir H, Boscolo FS et al. Increased risk of genetic and epigenetic instability in human embryonic stem cells associated with specific culture conditions. PLoS ONE 10, e0118307 (2015).

58. Rebuzzini P, Zuccotti M, Redi CA, Garagna S. Achilles' heel of pluripotent stem cells: genetic, genomic and epigenetic variations during prolonged culture. Cell Mol. Life Sci. 73, 2453-2466 (2016).

59. Lefort N, Feyeux M, Bas C et al. Human embryonic stem cells reveal recurrent genomic instability at 20q11.21. Nat. Biotechnol. 26, 1364-1366 (2008).

60. Bai Q, Ramirez JM, Becker F et al. Temporal analysis of genome alterations induced by single-cell passaging in human embryonic stem cells. Stem Cells Dev. 24, 653-662 (2014).

61. Tosca L, Feraud O, Magniez A et al. Genomic instability of human embryonic stem cell lines using different passaging culture methods. Mol. Cytogenet. 8, 30 (2015).

62. Garber K. RIKEN suspends first clinical trial involving induced pluripotent stem cells. Nat. Biotechnol. 33, 890-891 (2015).

63. Merkle FT, Ghosh S, Kamitaki N et al. Human pluripotent stem cells recurrently acquire and expand dominant negative P53 mutations. Nature 545(7653), 229-233 (2017).

64. Nouspikel T. Genetic instability in human embryonic stem cells: prospects and caveats. Future Oncol. 9, 867-877 (2013).

65. Varela C, Denis JA, Polentes J et al. Recurrent genomic instability of chromosome 1q in neural derivatives of human embryonic stem cells. J. Clin. Invest. 122, 569-574 (2012).

66. Rodríguez-Martínez D, Martínez-Losa MM, Alvarez-Dolado M. Cryopreservation of GABAergic neuronal precursors for cell-based therapy. PLoS ONE 12, e0170776 (2017).

67. Noisa P, Raivio T, Cui W. Neural progenitor cells derived from human embryonic stem cells as an origin of dopaminergic neurons. Stem Cells Int. 2015, 647437 (2015)

68. Studer L, Tabar V, McKay RD. Transplantation of expanded mesencephalic precursors leads to recovery in parkinsonian rats. Nat. Neurosci. 1, 290-295 (1998).

69. Cai J, Yang M, Poremsky E, Kidd S, Schneider JS, Iacovitti L. Dopaminergic neurons derived from human induced pluripotent stem cells survive and integrate into 6-OHDA-lesioned rats. Stem Cells Dev. 19, 1017-1023 (2010).

70. Hancock CR, Wetherington JP, Lambert NA, Condie BG. Neuronal differentiation of cryopreserved neural progenitor cells derived from mouse embryonic stem cells. Biochem. Biophys. Res. Commun. 271(2), 418-421 (2000).

71. Milosevic J, Storch A, Schwarz J. Cryopreservation does not affect proliferation and multipotency of murine neural precursor cells. Stem Cells 23(5), 681-688 (2005).

72. Wakeman DR, Hiller BM, Marmion DJ et al. Cryopreservation maintains functionality of human iPSC dopamine neurons and rescues parkinsonian phenotypes in vivo. Stem Cell Rep. 9, 149-161 (2017). 
Special Report Sebastian, Hourd, Chandra, Williams \& Medcalf

73. Duelen R, Sampaolesi M. Stem cell technology in cardiac regeneration: a pluripotent stem cell promise. EBioMedicine 16, 30-40 (2017).

74. Guzzo RM, Gibson J, Xu RH, Lee FY, Drissi H. Efficient differentiation of human iPSC-derived mesenchymal stem cells to chondroprogenitor cells. J. Cell. Biochem. 114(2), 480-490 (2012). 